ScIDice

\section{Assessment Of Internal Root Resorption Cases Reported To Private Dental Hospital - A Retrospective Study}

Research Article

Karthikeson. P.S ${ }^{1}$, Mahalakshmi $\mathrm{J}^{2 *}$, Kiran Kumar Pandurangan ${ }^{3}$

${ }^{1}$ Saveetha Dental College and Hospitals, Saveetha Institute of Medical and Technical Sciences (SIMATS), Saveetha University, Chennai - 600 077, India. ${ }^{2}$ Senior Lecturer, Department of Conservative Dentistry and Endodontics, Saveetha Dental College and Hospitals, Saveetha Institute of Medical and Technical Sciences (SIMATS), Saveetha University, Chennai - 600 077, India.

${ }^{3}$ Senior Lecturer, Department of Prosthodontics, Saveetha Dental College and Hospitals, Saveetha Institute of Medical and Technical Sciences (SIMATS), Saveetha University, Chennai - 600 077, India.

Abstract

Internal root resorption is an injury related reception involving roots of teeth. It will be asymptomatic but when the inflammation process happens, it communicates with the external tooth surface. In internal root resorption,the inflamed pulp tissue gets resorted within root structure. The tooth will remain asymptomatic until the inflammatory process communicates with the external tooth surface. The study is about investigating how many internal root resorption cases were reported to private dental hospital. Patients case records were reviewed and data related to internal resorption diagnosis and management were retrieved from total patients reports in between June 2019 and March 2020. Data were tabulated and statistical analysis was done using SPSS software(version 9.0.3). Three patients reported to hospital with internal root reception. Two patients were males and one patient was female. Teeth involved were $11,46,48$. Within the limitations of the current study, it was found that 3 patients reported for internal resorption management. Frequent follow up of patients should be done for better management of internal root resorption.

Keywords: Internal Resorption; Inflammatory Resorption; Osteoclasts; Perforation; Trauma.

\section{Introduction}

Internal root resorption is referred to the progressive destruction of intraradical dentin and dentinal tubules along the middle and apical third of the canal walls as a result of osteoclastic activities [1]. It is an injury related resorption to the roots of the teeth. The various aetiological factors for internal root resorption include traumatic injury, infection and orthodontic treatment [2]. In internal root resorption, the inflamed pulp tissue gets resorbed within root structure. The tooth will remain asymptomatic until the inflammatory process communicates with the external tooth surface [3]. A pink spot could also be present which represents the granulation tissue showing through the resorbed area. When examined through radiographs, there is a radiolucent enlargement of pulp space. Internal inflammatory root resorption is detected radiographically . Many periapical lesions are found during radio- graphic examination and some of which may be asymptomatic. As indicated earlier, diagnosis of symmetrical, round or oval lesions in the root canal can easily be done.[4] For more irregularly shaped resorptions, the key diagnostic feature is the disappearance of the original canal shape in the area of the resorption. Cervical or root surface caries seldom create a diagnostic problem even in cases where the radiolucent carious lesion projects on top of the root canal $[5,6]$. Color changes that are clinically visible are present only in a minority of cases of internal and cervical resorptions. The color change associated with internal resorption can be pink, red, dark red, gray or even dark gray which will depend on the size of the resorption and the vitality status of the pulp. Depending on the location reception will extend to coronal/cervical, middle or apical third portions [7]. This may end in delayed healing. Also it could also not be associated with bone with underlying periapical lesions of various sizes present. Pre-

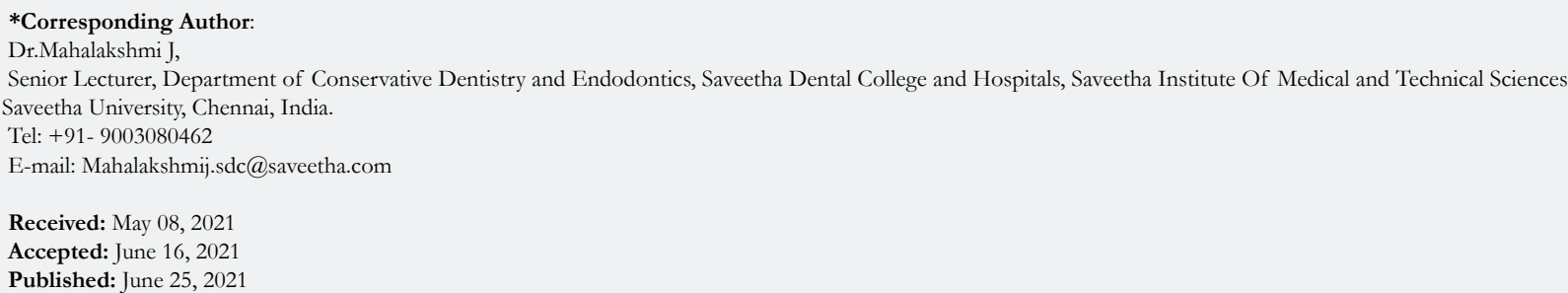

Copyright: Mahalakshmi J ${ }^{\odot}$ 2021. This is an open-access article distributed under the terms of the Creative Commons Attribution License, which permits unrestricted use, distribution and reproduction in any medium, provided the original author and source are credited. 
vious studies reported that only a few internal root resorption cases were reported to hospital. Lack of frequent following up of patients might be a reason for that.Previously our team has a rich experience in working on various research projects across multiple disciplines [8-22].

So the aim of our study was to find out the number of internal root resorption cases reported to private dental hospital.

\section{Materials And Methods}

It was a university setting and a retrospective analysis done from June 2019 to March 2020. Saveetha Dental College, Chennai, TamilNadu was selected as the study area. Chennai is a metropolitan city with a diverse population of people from different socio economic background. Patients from the same geographical location were selected as the study population. All patients reported to Saveetha Dental College were included in inclusion criteria. Those who were not willing to participate in this study were considered in exclusion criteria. Ethical approval was obtained from the Institutional Ethical committee of Saveetha University. Pa- tients reported to Saveetha dental college were taken as full unit. Patient records were reviewed and data related to internal resorption management were reviewed. Data were tabulated in the excel sheet. Statistical analysis was done using SPSS software(version 9.0.3). Statistical test included Chi square association analysis.

\section{Results And Discussion}

In this study, the number of cases reported to private dental hospital out of which the cases referred for internal root resorption management, those cases are separately identified. Three patients were identified where 2 were males and 1 was female. Through SPSS analysis, frequency distribution is done among two variables - gender and tooth number with number of internal root resorption cases. Males are more in number than female [Figure 1] 11, 46,48 are the teeth in which internal root resorption occurred [Figure 2]. Each one case of internal root resorption was reported in 11,46 and 48 . Chi square test- $p$ value $=0.223(\mathrm{p}>0.05)$ indicating not statistically significant [Figure 3].

Three patients were identified where 2 were males and 1 was fe-

Figure 1. Bar Graph represents frequency of gender distribution with number of internal root resorption cases. $\mathrm{X}$ axis refers to gender and $\mathrm{Y}$ axis refers to number of internal root resorption cases.Red colour denotes male and blue colour denotes female. Graph 1 shows that 2(66.67\%) Male patients and 1(33.37\%) female reported to the hospital with internal root resorption.

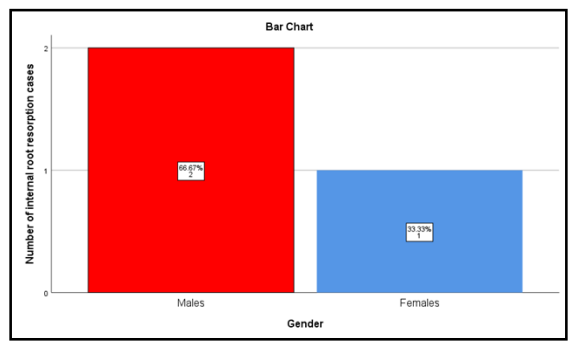

Figure 2. Bar graph represents the frequency distribution of tooth number with the number of internal root resorption cases . $\mathrm{X}$ axis refers to the tooth number and $\mathrm{Y}$ axis refers to the number of internal root resorption cases. Green colour denotes 11, pink colour denotes 46 and grey colour denotes 48 . Each one case of internal root resorption was reported in 11,46 and 48.

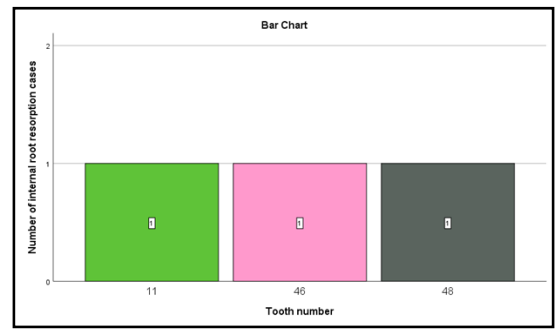

Figure 3. Bar graph represents the association of tooth number with gender. $\mathrm{X}$ axis refers to the tooth number and $\mathrm{Y}$ axis refers to the number of internal root resorption cases. Among the 3 internal root resorption cases reported, 2 were male and 1 was female. Each one case of internal root resorption was reported in 11,46 and 48 . Chi square test- $p$ value $=0.223(p>0.05)$ hence not statistically significant.

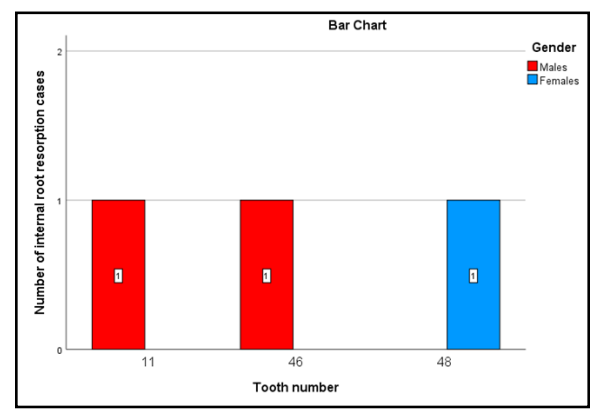


male. Mittal et al [23] reported that, in his study 3 patients reported with internal inflammatory resorption. In Minciks study [24], he stated that two internal root resorption cases were reported. By looking into the studies, prevalence between $0.01 \%$ and $1 \%$ patients affected by internal root resorption is observed. These findings might be minimal but it is estimated that one only one tooth per patient is affected by internal root resorption. But for some cases, more than two adjacent teeth can have internal root resorption in case of trauma. Wedenberg \& Zetterqvist [25] examined 13 primary and permanent teeth extracted because of internal resorption. The authors reported that the progress of the resorption was faster in primary teeth, but that there were no other differences between the two groups of teeth. The pulp tissue next to the resorption showed hyperemia and varying degrees of inflammation and infiltration of lymphocytes, macrophages, and neutrophilic leukocytes. Bacteria were detected histologically only in the teeth undergoing rapidly progressing resorption. They also reported osteoid/cementum-like tissue in some areas of the pulpal wall as well as small calcifications in the pulp tissue. Internal inflammatory root resorptions continue to expand until either endodontic treatment is started or the pulp becomes necrotic. Perforation of the root is usually followed by the development of a sinus tract, which confirms the presence of an infection in the root canal. After the perforation, the continuation of the resorption may no longer be dependent on the presence of vital pulp tissue because of the effect on the pathogenesis or symptoms of apical periodontitis. In its most classical appearance, internal inflammatory root resorption is relatively easy to identify radiographically and the correct diagnosis can be made. The resorption is seen as a radiolucent, round and symmetrical widening of the root canal space. At the area of the resorption, the original canal shape can no longer be observed. However, not all internal root resorptions show similar progression, and oval as well as asymmetrically shaped internal root resorptions can be found in the coronal pulp/crown area, internal resorption can be symmetrical in teeth with one root canal and a narrow pulp chamber where pulp horns are situated close to each other. However, in molar teeth with several roots and a wide pulp chamber, internal resorption may begin at one part of the chamber and spread locally into the surrounding dentin. Recent evolution of radiographic techniques has begun to have an impact on the diagnosis of tooth resorptions, including internal root resorption. Assessment of the resorptive lesions by three-dimensional imaging using various modifications of the CT techniques will greatly facilitate differential diagnosis and help to determine the location, dimensions, spreading, and possible sites of perforation in teeth.

Internal root resorption management can be done using irrigants such as hypochlorite and chlorhexidine. Use of hypochlorite helps control the bleeding from perforation sites. It disinfects the perforating area, in case of accidental perforations. In case of large perforations, low-concentration hypochlorite solutions and chlorhexidine are considered. The reciprocal activity between the granular tissue and dentinoclasts inside the endodontic space could be compared to pathogenetic changes in the periapical region. Early diagnosis and treatment planning is very important in order to stop the resorption process. Hence it is necessary to initiate endodontic treatment as soon as possible to arrest the progression of the resorptive process and to prevent root or cervical crown fracture. Root resorption is a complex process. At present the internal inflammatory resorption can be controlled. But internal replacement resorption is difficult to control. Prevention should be the best approach. Root canal treatment is still considered as the treatment of choice of internal root resorption as it removes the granulation tissue and blood supply of the clastic cells. The access cavity preparation must be done in a conservative manner to preserve tooth structure and avoid further weakening of the already compromised tooth. Continuous bleeding inside might impair visibility in teeth with active lesions until the apical pulp tissue is removed. The shape of the resorption defect usually makes it inaccessible to direct mechanical instrumentation. A great emphasis must be placed on the chemical dissolution of the vital and necrotic pulp tissue with sodium hypochlorite.The use of calcium hydroxide as an interappointment dressing maximizes the effect of disinfection procedures, helps to control the bleeding, and necrotizes residual pulp tissue.The root canal filling material needs to be flowable to seal the defects. Thermoplastic guttapercha give the best results when the canal walls are respected. MTA is considered as the material of choice to seal the perforation as it is biocompatible, bioactive, and well tolerated by periradicular tissues.Our institution is passionate about high quality evidence based research and has excelled in various fields [26-36]. Limitation of our current study was found to be smaller sample size. Hence larger sample size and with randomised controlled trials, better assessment of internal root resorption can be done.

\section{Conclusion}

This study reported three internal root resorption cases with $66.67 \%$ male and $33.37 \%$ female patients and one in each tooth (11,46 and 48). It is of utmost importance to manage internal root resorption at the earliest stage or it will lead to communication between pulp and periodontium thereby resulting in perio - endo communication. It is necessary for the practitioners to recall patients for better management of internal root resorption in near future.

\section{Acknowledgement}

We, the authors of the manuscript, would like to thank and acknowledge Saveetha Dental College for providing us access to use the data for our study.

\section{Author Contributions}

All authors have equal contribution in bringing out this research work.

\section{Conflict Of Interest}

This research project is self funded and it is not sponsored or aided by any third party. There is no conflict of interest.

\section{References}

[1]. Patel S, Ricucci D, Durak C, Tay F. Internal root resorption: a review. J Endod. 2010 Jul 1;36(7):1107-21.

[2]. Sameshima GT, Sinclair PM. Predicting and preventing root resorption: Part I. Diagnostic factors. Am J Orthod Dentofacial Orthop. 2001 May 1;119(5):505-10.

[3]. Fernandes M, de Ataide I, Wagle R. Tooth resorption part I - pathogenesis and case series of internal resorption. J Conserv Dent. 2013 Jan;16(1):4-8. Pubmed PMID: 23349568.

[4]. Teixeira FB. Endodontics: Principles and Practice. J. Endod. 2009 Jul 
$1 ; 35(7): 474$.

[5]. Nilsson E, Bonte E, Bayet F, Lasfargues JJ. Management of internal root resorption on permanent teeth. Int J Dent. 2013 Nov 21;2013:929486.

[6]. Tronstad L. Root resorption--etiology, terminology and clinical manifestations. Endod Dent Traumatol. 1988 Dec;4(6):241-52.Pubmed PMID: 3078294.

[7]. Ne RF, Witherspoon DE, Gutmann JL. Tooth resorption. Quintessence Int. 1999 Jan 1;30:9-25.

[8]. Hafeez N. Accessory foramen in the middle cranial fossa. Res J Pharm Technol. 2016 Nov 1;9(11):1880.

[9]. Krishnan RP, Ramani P, Sherlin HJ, Sukumaran G, Ramasubramanian A, Jayaraj G, et al. Surgical Specimen Handover from Operation Theater to Laboratory: A Survey. Ann Maxillofac Surg. 2018 Jul-Dec;8(2):234-238. Pubmed PMID: 30693238.

[10]. Somasundaram S, Ravi K, Rajapandian K, Gurunathan D. Fluoride Content of Bottled Drinking Water in Chennai, Tamilnadu. J Clin Diagn Res. 2015 Oct;9(10):ZC32-4.Pubmed PMID: 26557612.

[11]. Felicita AS. Orthodontic extrusion of Ellis Class VIII fracture of maxillary lateral incisor - The sling shot method. Saudi Dent J. 2018 Jul;30(3):265269.Pubmed PMID: 29942113.

[12]. Kumar S, Rahman RE. Knowledge, awareness, and practices regarding biomedical waste management among undergraduate dental students. Asian J Pharm Clin Res. 2017;10(8):341.

[13]. Gurunathan D, Shanmugaavel AK. Dental neglect among children in Chennai. J Indian Soc Pedod Prev Dent. 2016 Oct 1;34(4):364.

[14]. Sneha S. Knowledge and awareness regarding antibiotic prophylaxis for infective endocarditis among undergraduate dental students. Asian J Pharm Clin Res. 2016 Oct 1:154-9.

[15]. Dhinesh B, Lalvani JI, Parthasarathy M, Annamalai K. An assessment on performance, emission and combustion characteristics of single cylinder diesel engine powered by Cymbopogon flexuosus biofuel. Energy Convers. Manag. 2016 Jun 1;117:466-74.

[16]. Choudhari S, Thenmozhi MS. Occurrence and Importance of Posterior Condylar Foramen. LATERALITY. 2016 Aug 28;8:11-43.

[17]. Paramasivam A, Vijayashree Priyadharsini J, Raghunandhakumar S. N6adenosine methylation (m6A): a promising new molecular target in hypertension and cardiovascular diseases. Hypertens Res. 2020 Feb;43(2):153154.Pubmed PMID: 31578458.

[18]. Wu F, Zhu J, Li G, Wang J, Veeraraghavan VP, Krishna Mohan S, et al. Biologically synthesized green gold nanoparticles from Siberian ginseng induce growth-inhibitory effect on melanoma cells (B16). Artif Cells Nanomed Biotechnol. 2019 Dec;47(1):3297-3305.Pubmed PMID: 31379212.

[19]. Palati S, Ramani P, Shrelin HJ, Sukumaran G, Ramasubramanian A, Don $\mathrm{KR}$, et al. Knowledge, Attitude and practice survey on the perspective of oral lesions and dental health in geriatric patients residing in old age homes. Indian J Dent Res. 2020 Jan-Feb;31(1):22-25.Pubmed PMID: 32246676.

[20]. Saravanan M, Arokiyaraj S, Lakshmi T, Pugazhendhi A. Synthesis of silver nanoparticles from Phenerochaete chrysosporium (MTCC-787) and their antibacterial activity against human pathogenic bacteria. Microb Pathog. 2018 Apr;117:68-72.Pubmed PMID: 29427709.

[21]. Govindaraju L, Gurunathan D. Effectiveness of Chewable Tooth Brush in Children-A Prospective Clinical Study. J Clin Diagn Res. 2017 Mar;11(3):ZC31-ZC34.Pubmed PMID: 28511505.

[22]. Vijayakumar Jain S, Muthusekhar MR, Baig MF, Senthilnathan P, Loganathan S, Abdul Wahab PU, et al. Evaluation of Three-Dimensional Changes in Pharyngeal Airway Following Isolated Lefort One Osteotomy for the Correction of Vertical Maxillary Excess: A Prospective Study. J Maxillofac Oral Surg. 2019 Mar;18(1):139-146.Pubmed PMID: 30728705.

[23]. Mittal S, Kumar T, Mittal S, Sharma J. Internal root resorption: An endodontic challenge: A case series. J Conserv Dent. 2014 Nov;17(6):590-3.

[24]. Mincik J, Urban D, Timkova S. Clinical Management of Two Root Resorption Cases in Endodontic Practice. Case Rep Dent. 2016;2016:9075363. Pubmed PMID: 27648314.

[25]. Wedenberg C, Zetterqvist L. Internal resorption in human teeth--a histological, scanning electron microscopic, and enzyme histochemical study. J Endod. 1987 Jun;13(6):255-9.Pubmed PMID: 3474343.

[26]. Vijayashree Priyadharsini J. In silico validation of the non-antibiotic drugs acetaminophen and ibuprofen as antibacterial agents against red complex pathogens. J Periodontol. 2019 Dec;90(12):1441-1448.Pubmed PMID: 31257588.

[27]. PC J, Marimuthu T, Devadoss P, Kumar SM. Prevalence and measurement of anterior loop of the mandibular canal using CBCT: A cross sectional study. Clin Implant Dent Relat Res. 2018 Apr 6;20(4):531-4.

[28]. Ramesh A, Varghese S, Jayakumar ND, Malaiappan S. Comparative estimation of sulfiredoxin levels between chronic periodontitis and healthy patients - A case-control study. J Periodontol. 2018 Oct;89(10):1241-1248.Pubmed PMID: 30044495

[29]. Ramadurai N, Gurunathan D, Samuel AV, Subramanian E, Rodrigues SJ. Effectiveness of $2 \%$ Articaine as an anesthetic agent in children: randomized controlled trial. Clin Oral Investig. 2019 Sep;23(9):3543-50.

[30]. Sridharan G, Ramani P, Patankar S, Vijayaraghavan R. Evaluation of salivary metabolomics in oral leu..........koplakia and oral squamous cell carcinoma. J Oral Pathol Med. 2019 Apr;48(4):299-306.

[31]. Ezhilarasan D, Apoorva VS, Ashok Vardhan N. Syzygium cumini extract induced reactive oxygen species-mediated apoptosis in human oral squamous carcinoma cells. J Oral Pathol Med. 2019 Feb;48(2):115-121.Pubmed PMID: 30451321.

[32]. Mathew MG, Samuel SR, Soni AJ, Roopa KB. Evaluation of adhesion of Streptococcus mutans, plaque accumulation on zirconia and stainless steel crowns, and surrounding gingival inflammation in primary molars: randomized controlled trial. Clin Oral Investig. 2020 Sep;24(9):3275-3280.Pubmed PMID: 31955271.

[33]. Samuel SR. Can 5-year-olds sensibly self-report the impact of developmental enamel defects on their quality of life? Int J Paediatr Dent. 2021 Mar;31(2):285-286.Pubmed PMID: 32416620.

[34]. R H, Ramani P, Ramanathan A, R JM, S G, Ramasubramanian A, et al. CYP2 C9 polymorphism among patients with oral squamous cell carcinoma and its role in altering the metabolism of benzo[a]pyrene. Oral Surg Oral Med Oral Pathol Oral Radiol. 2020 Sep;130(3):306-312.Pubmed PMID: 32773350 .

[35]. Chandrasekar R, Chandrasekhar S, Sundari KKS, Ravi P. Development and validation of a formula for objective assessment of cervical vertebral bone age. Prog Orthod. 2020 Oct 12;21(1):38.Pubmed PMID: 33043408.

[36]. Vijayashree Priyadharsini J, Smiline Girija AS, Paramasivam A. In silico analysis of virulence genes in an emerging dental pathogen A. baumannii and related species. Arch Oral Biol. 2018 Oct;94:93-98.Pubmed PMID: 30015217. 